\title{
EFFECT OF PARAMETERS LIKE SPINDLE SPEED, DEPTH OF CUT AND FEED RATE ON THE CUTTING FORCE OF A SINGLE POINT CUTTING TOOL
}

\author{
Bharat Sharma \\ School Of Mechanical Engineering \\ Vellore Institute Of Technology, Chennai, Tamil Nadu, India
}

\begin{abstract}
In the turning operation performed on a lathe machine, various parameters affect the tool performance and ultimately the wear of the tool which is directly related to the cutting force of the tool. This paper aims to give an insight into how cutting force varies when the above parameters are varied and finally arrive at a conclusion on how to decrease the cutting force. The decrease in the cutting force will ensure easy machining operation. The measurement of cutting forces in machining operation is crucial to estimate the power consumption and to arrive at an economic solution. The cutting forces on a single point cutting tool can be measured and evaluated by a variety of methods; the measurement of cutting force with the help of a suitable dynamometer is used in industries regularly. Mechanical and strain gauge dynamometer are the two most broadly used types for measuring forces in machining operation. The dynamometer works on the principle of the measurement of deflections or strain produced on the dynamometer structure from the action of cutting force. In this experiment-based study, a lathe tool dynamometer is used to measure the cutting force. The specifications of the dynamometer used in the study are $200 \mathrm{~kg}$ force and 3 component system. The dynamometer is connected to a data acquisition system (DAQ). In this experimental work, the forces in the three spatial directions have been noted using a mild steel specimen.
\end{abstract}

Keywords: Mild steel, single-point cutting tool, Lathe tool dynamometer, spindle speed, depth of cut, feed rate.

\section{INTRODUCTION}

The three requirements of the process of metal cutting are

1. Cutting tool

2. Work-piece
3. Relative motion between tool and workpiece.

A machine-tool dynamometer is a multicomponent dynamometer that is used to measure the cutting force during the machining operation using a tool. With recent advancements in technology, the use of machine-tool dynamometers is increasing and is used to accurately measure the cutting forces and optimize the process of machining. The cutting force is measured by the multi-component by measuring the forces in each of the three spatial dimensions. The cutting force during machining is dependent on various parameters like depth of cut, feed rate, speed of the spindle, tool geometry, material of the workpiece and material of the tool.

\section{IMAGES}

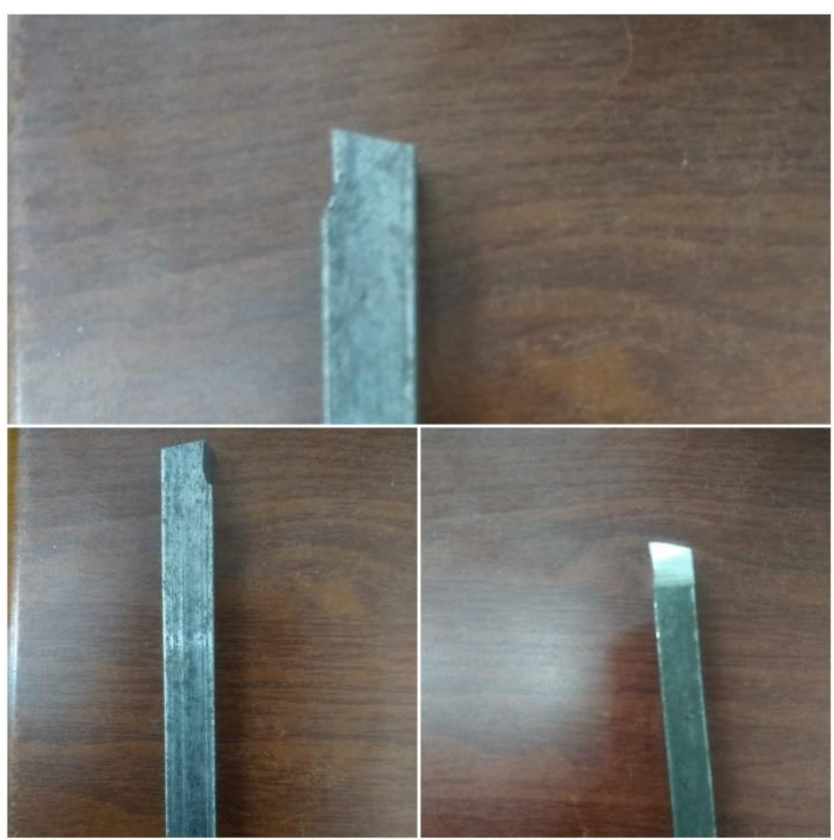

Figure 1: Cutting Tool Used For The Study 
International Journal of Engineering Applied Sciences and Technology, 2020 Vol. 4, Issue 12, ISSN No. 2455-2143, Pages 525-530

Published Online April 2020 in IJEAST (http://www.ijeast.com)

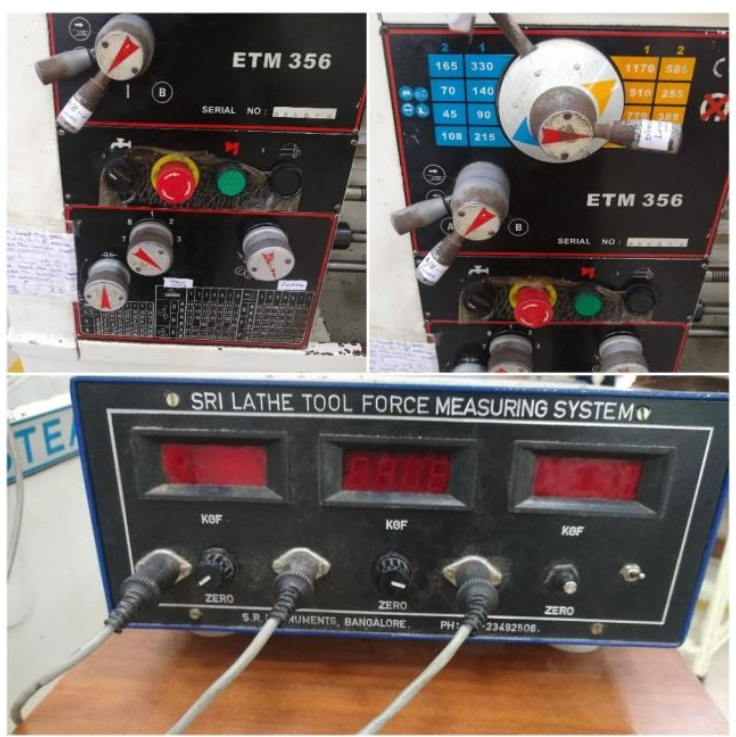

Figure 2: Lathe Machine And Machine-Tool Dynamometer

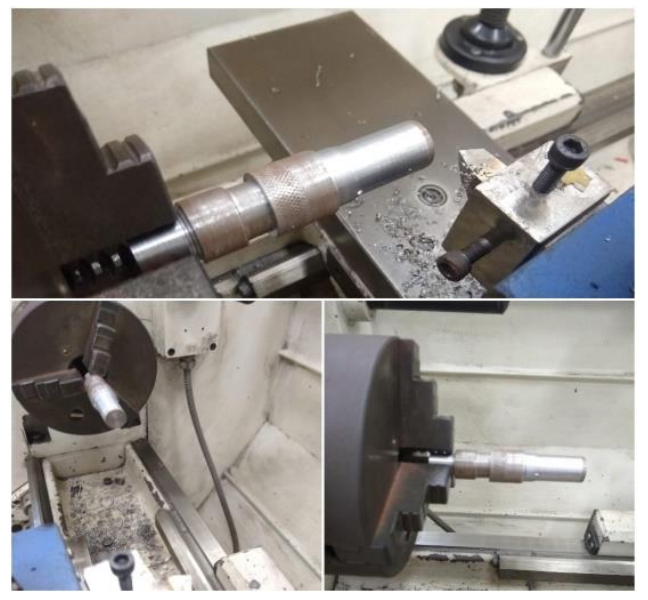

Figure 3: Turning Operation For The Study

III. SPECIFICATIONS OF THE MACHINES AND INSTRUMENTS INVOLVED

\section{LATHE MACHINE:}

\begin{tabular}{|l|l|}
\hline MAKE & ESTEEM \\
\hline MODEL & ETM 356 \\
\hline SWING OVER BED & $330 \mathrm{~mm}$ \\
\hline $\begin{array}{l}\text { SWING OVER CROSS } \\
\text { SLIDE }\end{array}$ & $195 \mathrm{~mm}$ \\
\hline WIDTH OF BED & $206 \mathrm{~mm}$ \\
\hline
\end{tabular}

\begin{tabular}{|ll|l|}
\hline $\begin{array}{l}\text { DISTANCE } \\
\text { CENTRES }\end{array}$ & BETWEEN & $1000 \mathrm{~mm}$ \\
\hline $\begin{array}{l}\text { NUMBER OF } \\
\text { SPEED }\end{array}$ & SPINDLE & $\begin{array}{l}16(2 \\
\text { MOTOR })\end{array}$ \\
\hline $\begin{array}{l}\text { RANGE OF } \\
\text { SPEED }\end{array}$ & SPINDLE & $45-1800 \mathrm{rpm}$ \\
\hline MOTOR CAPACITY & $3 \mathrm{HP}$ \\
\hline
\end{tabular}

TOOL:

\begin{tabular}{|c|c|}
\hline TOOL MATERIAL & HSS \\
\hline RAKE ANGLE & 5 degrees \\
\hline SIDE RAKE ANGLE & 7 degrees \\
\hline NOSE RADIUS & $0.5 \mathrm{~mm}$ \\
\hline SIDE CUTTING EDGE ANGLE & 11 degrees \\
\hline RELIEF ANGLE & 8 degrees \\
\hline END CUTTING EDGE ANGLE & 10 degrees \\
\hline END RELIEF ANGLE & 14 degrees \\
\hline
\end{tabular}

SPECIMEN

\begin{tabular}{|l|l|}
\hline MATERIAL & MILD STEEL \\
\hline DIAMETER & $24 \mathrm{~mm}$ \\
& \\
\hline
\end{tabular}


Published Online April 2020 in IJEAST (http://www.ijeast.com)

\begin{tabular}{|l|l|}
\hline LENGTH & $150 \mathrm{~mm}$ \\
& \\
\hline OPERATIONS & TURNING \\
& \\
\hline
\end{tabular}

MACHINE-TOOL DYNAMOMETER:

\begin{tabular}{|l|l|}
\hline MAKE & S R INSTRUMENTS \\
\hline SOURCE & $220 \mathrm{~V}$ \\
\hline FREQUENCY & $50-60 \mathrm{z}$ \\
& \\
\hline
\end{tabular}

\section{VARIOUS CUTTING FORCES DURING THE TURNING OPERATION}

It is important to have the knowledge of various cutting forces developed during the turning operation under given cutting factors as it is of great importance, being dominant criteria for knowing the machinability of the material, it also enables a transparent idea between both the manufacturer of the tool and the one designing it, as well as to the user. Moreover, knowing the facts beforehand helps in the analysis of the problems in machining economics and optimizing the solutions.

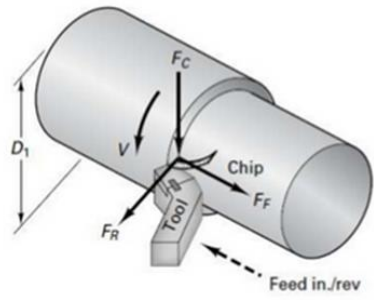

3 Force

$F_{C}=$ Cutting force (vertical $F_{R}=$ Radial force (thrust) $F_{F}=$ Feed force

\section{TERMINOLOGY AND ABBREVIATION:}

1. Fx- feed force

2. Fy-cutting force

3. Fz-radial force

\section{PROCEDURE}

1. The workpiece is held in the 3-jaw chuck.

2. Perform facing operation to make the end face of the given workpiece flat.

3. Feed the tool manually to start the machining operation

4. Feed the tool automatically automatically.

5. Connect the force Indicator to a $230 \mathrm{~V}$, singlephase supply and switch on the power supply.

6. Wait for a couple of minutes to balance the channels.

7. Set the readings on display to zero.

8. The forces generated during the machining operation are measured by varying the cutting speed by keeping the depth of cut and feed rate constant.

9. Repeated the above procedure by varying depth of cut with constant cutting speed, feed and by varying feed with constant cutting speed, depth of cut.

\section{OBSERVATIONS}

$>$ FORMULA USED TO CALCULATE Fr(RESULTANT FORCE) IS:

$\left(\mathrm{Fx}^{\wedge} 2+\mathrm{Fy}^{\wedge} 2+\mathrm{Fz}^{\wedge} 2\right)^{\wedge} 1 / 2 \rightarrow \mathrm{BY}$ THE VECTOR ADDITION PROPERTY.

- CONSTANT SPINDLE SPEED AND FEED

\begin{tabular}{|c|c|c|c|c|c|c|c|}
\hline $\begin{array}{l}\text { SN } \\
\mathrm{O}\end{array}$ & $\begin{array}{l}\text { SPINDLE } \\
\text { SPEED } \\
(\mathrm{rpm})\end{array}$ & $\begin{array}{l}\text { FEED } \\
(\mathrm{mm} / \mathrm{re} \\
\mathrm{v})\end{array}$ & $\begin{array}{l}\text { DEPTH } \\
\text { OF CUT } \\
(\mathrm{mm})\end{array}$ & $\begin{array}{l}\mathrm{F} \\
\mathrm{x} \\
( \\
\mathrm{N} \\
)\end{array}$ & $\begin{array}{l}\mathrm{F} \\
\mathrm{y} \\
( \\
\mathrm{N} \\
)\end{array}$ & $\begin{array}{l}\mathrm{F} \\
\mathrm{z} \\
( \\
\mathrm{N} \\
)\end{array}$ & $\mathbf{F r}$ \\
\hline 1 & 510 & 0.135 & 0.4 & $\begin{array}{l}0 . \\
1\end{array}$ & $\begin{array}{l}0 . \\
5\end{array}$ & $\begin{array}{l}0 . \\
9\end{array}$ & $\begin{array}{l}1.0 \\
34\end{array}$ \\
\hline 2 & 510 & 0.135 & 0.8 & $\begin{array}{l}0 . \\
4\end{array}$ & $\begin{array}{l}\text { 0. } \\
7\end{array}$ & $\begin{array}{l}2 . \\
1\end{array}$ & $\begin{array}{l}2.2 \\
49\end{array}$ \\
\hline 3 & 510 & 0.135 & 1.2 & $\begin{array}{l}1 . \\
2\end{array}$ & $\begin{array}{l}1 . \\
3\end{array}$ & $\begin{array}{l}4 . \\
1\end{array}$ & $\begin{array}{l}4.4 \\
65\end{array}$ \\
\hline
\end{tabular}

- CONSTANT SPINDLE SPEED AND DEPTH OF CUT

\begin{tabular}{|c|c|c|c|c|c|c|c|}
\hline $\begin{array}{l}\text { SN } \\
\mathrm{O}\end{array}$ & $\begin{array}{l}\text { SPIN } \\
\text { DLE } \\
\text { SPEE } \\
\text { D } \\
(\mathrm{rpm})\end{array}$ & $\begin{array}{l}\text { FEE } \\
\mathrm{D} \\
(\mathrm{mm} / \\
\mathrm{rev})\end{array}$ & $\begin{array}{l}\text { DEPT } \\
\text { H OF } \\
\text { CUT( } \\
\text { mm) }\end{array}$ & $\begin{array}{l}F \\
\mathrm{X} \\
( \\
\mathrm{N} \\
)\end{array}$ & $\begin{array}{l}\text { F } \\
y \\
( \\
N \\
)\end{array}$ & $\begin{array}{l}\mathrm{F} \\
\mathrm{Z} \\
( \\
\mathrm{N} \\
)\end{array}$ & Fr \\
\hline 1 & 770 & 0.070 & 0.5 & $\begin{array}{l}\text { 0. } \\
1\end{array}$ & $\begin{array}{l}\mathbf{0 .} \\
9\end{array}$ & $\begin{array}{l}0 . \\
4\end{array}$ & $\begin{array}{l}0.9 \\
9\end{array}$ \\
\hline 2 & 770 & 0.122 & 0.5 & $\begin{array}{l}\text { 0. } \\
2\end{array}$ & $\begin{array}{l}1 . \\
3\end{array}$ & $\begin{array}{l}\mathbf{0 .} \\
5\end{array}$ & $\begin{array}{l}1.4 \\
07\end{array}$ \\
\hline 3 & 770 & 0.214 & 0.5 & $\begin{array}{l}\text { 0. } \\
2\end{array}$ & $\begin{array}{l}2 . \\
7\end{array}$ & 1 & $\begin{array}{l}2.7 \\
\mathbf{0 7}\end{array}$ \\
\hline
\end{tabular}


- CONSTANT FEED AND DEPTH OF CUT

\begin{tabular}{|c|c|c|c|c|c|c|c|}
\hline $\begin{array}{l}\mathrm{S} \\
\mathrm{N}\end{array}$ & $\begin{array}{l}\text { SPIN } \\
\text { DLE } \\
\text { SPEE } \\
\text { D } \\
\text { (rpm) }\end{array}$ & $\begin{array}{l}\text { FEE } \\
\mathrm{D} \\
(\mathrm{mm} \\
/ \mathrm{rev})\end{array}$ & $\begin{array}{l}\text { DEPT } \\
\text { H OF } \\
\text { CUT } \\
(\mathrm{mm})\end{array}$ & $\begin{array}{l}\text { Fx } \\
(\mathrm{N})\end{array}$ & $\begin{array}{l}\text { Fy } \\
(\mathrm{N}\end{array}$ & $\begin{array}{l}\mathrm{Fz} \\
(\mathrm{N} \\
)\end{array}$ & $\begin{array}{l}\mathbf{F r} \\
\mathbf{( N} \\
)\end{array}$ \\
\hline 1 & 255 & $\begin{array}{l}0.14 \\
9\end{array}$ & 0.6 & 0.3 & 2.6 & 2.7 & $\begin{array}{l}3 . \\
76 \\
\end{array}$ \\
\hline 2 & 385 & $\begin{array}{l}0.14 \\
9\end{array}$ & 0.6 & 0.3 & 2.2 & 0.9 & $\begin{array}{l}2 . \\
39\end{array}$ \\
\hline 3 & 585 & $\begin{array}{l}0.14 \\
9 \\
\end{array}$ & 0.6 & 0.3 & 2.0 & 1.0 & 2. \\
\hline
\end{tabular}

VII. RESULTS

\section{CUTTING FORCE VS DEPTH OF CUT}

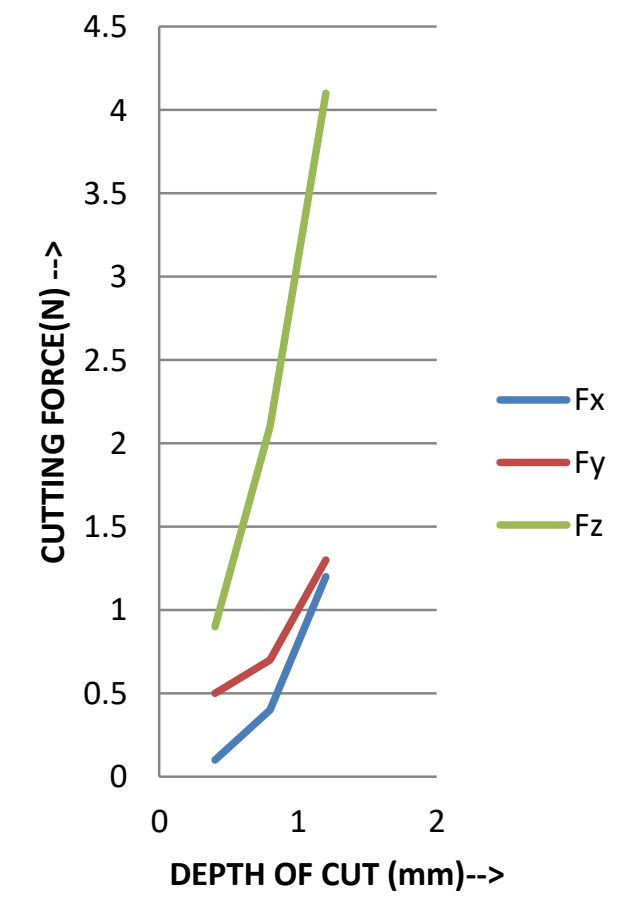

CUTTING FORCE VS FEED RATE

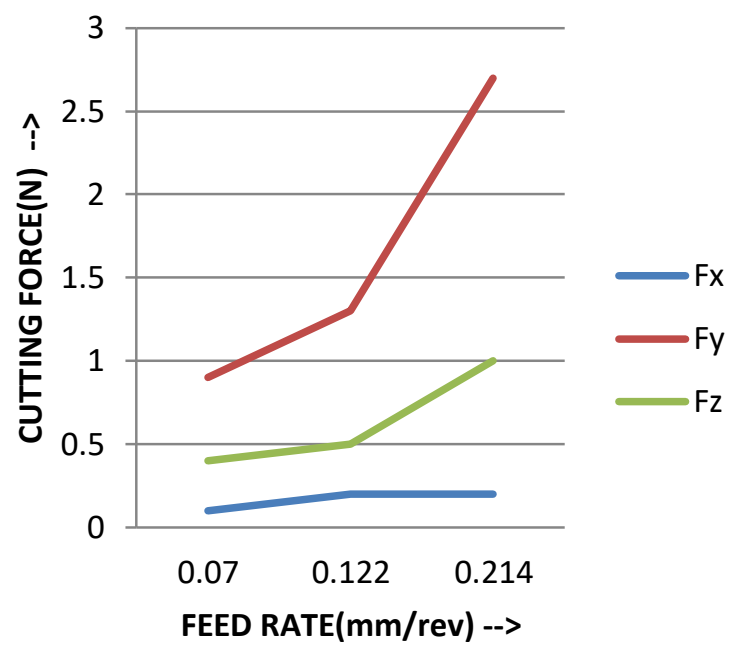

\section{CUTTING FORCE} VS SPINDLE SPEED

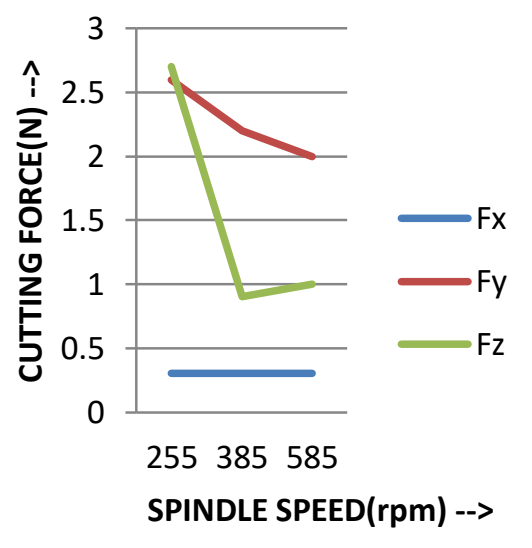


VARIATION OF RESULTANT CUTTING FORCE W.R.T VARYING PARAMETERS
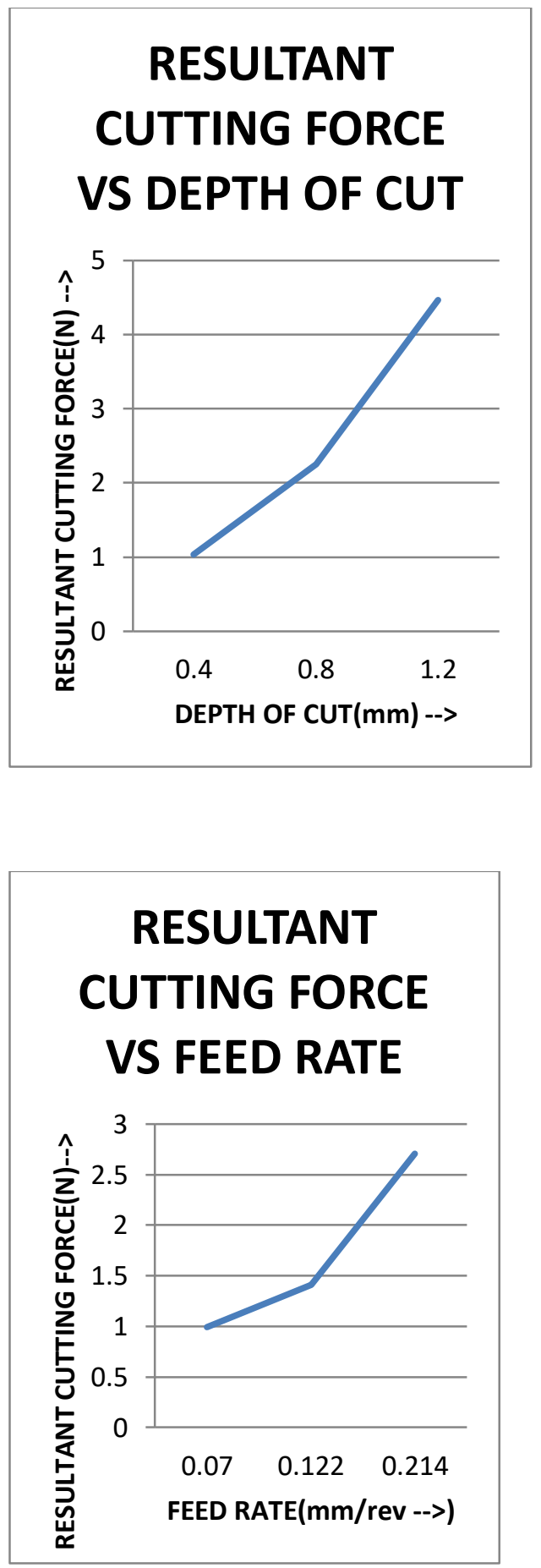

\section{RESULTANT CUTTING FORCE VS SPINDLE SPEED}

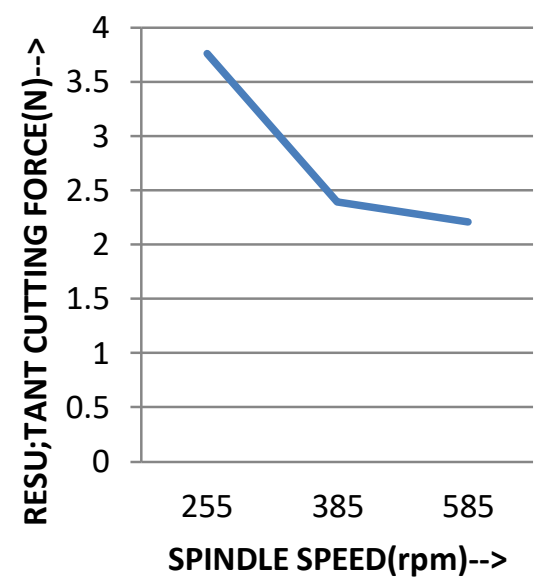

VIII. ANALYSIS OF THE RESULTS

From the above graphs, we can derive the following results

1. As the depth of cut increases the feed force cutting force and the radial force all increase respectively.

2. As the feed rate increases the feed force remains almost constant however the cutting force and radial force increase respectively.

3. As the spindle speed increases the feed force almost remains constant however, the radial force varies unusually and the cutting force decreases.

4. As the depth of cut increases the resultant cutting force increases.

5. As the feed rate increases the resultant cutting force increases.

6. As the spindle speed increases the resultant cutting force decreases.

\section{INFERENCE}

$>$ Depth of cut- The radial component Fz increases in the same ratio as the depth of cut.

$>$ Feed- The components of cutting force are greatly influenced by the feed rate. It can be observed that cutting force change is 
exponential at lower speeds but linear at higher speeds.

$>$ Cutting speed- It can be observed that the cutting force starts decreasing and becomes stable at higher speeds. The cutting forces at high speeds decrease because of high temperature at the toolwork interface which tend to make the material plastic, this concept is known as thermal softening and is beneficial in the turning operation as the cutting force decreases because of this.

\section{CONCLUSION}

This study proves the concept of thermal softening in the machining process such as turning. Hence, from the above study and analysis it is concluded that for an optimal turning operation the following should be the parameters:

1. High spindle speed

2. Medium feed rate

3. Low depth of cut

\section{REFERENCES}

[1] Factors Influencing Cutting Forces in Turning and Development of Software to Estimate Cutting Forces in Turning by Dr. R. R. Malagi, Rajesh. B. C., International Journal of Engineering and Innovative Technology (IJEIT) Volume 2, Issue 1, July 2012

[2] Manufacturing Process for Engineering materials by Serope Kalpakjian Steven R. Schmid $3^{\text {rd }}$ edition.

[3] https://www.sciencedirect.com/topics/engi neering/thermal-softening

[4] https://en.wikipedia.org/wiki/Turning

[5] Lathe Machine Basics: Introduction to Turning Operations by George Haynes.

[6] Süleyman YALDIZ -Development and Testing of a Cutting Force Dynamometer for Milling; Journal of Polytechnic. Volume 8, issue, 2005,(pg. 62-68)

[7] Cutting temperatures and their effects on the machining behaviour in drilling reinforced plastic composites by $\mathrm{K}$. Weinert and C. Kempmann, volume 6, issue 8, August 2004, (pg. 684-689)

[8] Y. Huang, S.Y. Liang —Cutting forces modeling considering the effect of tool thermal property - application to $\mathrm{CBN}$ hard turning International; Journal of Machine Tools \& Manufacture. 2003, (pg. 309-315) 